\title{
Letter to the Editor: Is Golf the New Football or Have We Made It So?
}

Sir,

We read with interest the article by Goebel et al. [1] (Goebel D, Drollinger F, Drollinger A. Lumbar Spine Injuries: Primary Prevention in Amateur and Professional Golf Players. Sports Med Int Open. 2018; 2:179-184). We have been deeply interested in this sport and delved on the musings of competitiveness causing athletes to put un-natural strains on their bodies and vice-versa. While we do understand the cause of Lumbar spine injuries caused by athletes putting undue stress on their bodies, we need to understand that the reason for the same.

If we have a look at the driving distances of pro-golfers over the years [2] ( Table 1) we will notice that Dan Pohl held the lead averaging 274.3 yards per drive with the tours average being a paltry 256.89 yards. Since then the average distance has kept on increasing with the maximum increase being in the year 2003. What is even more striking is that despite his numerous PGA titles, Tiger Woods never features on the leader board. So are we missing something here which is not entirely explained by just the golf swing of the players as has been beautifully explained by the author?

There are many factors that we might have overlooked. The physical condition of the golfers is now better than before. The clubs they use are no longer wooden. In fact, they are now made using titanium or zirconia and are now computer designed for greater durability, accuracy and balanced weight distribution, the driver's heads have become larger for better distance and accuracy. Golf courses are now better maintained. They are regularly mowed and grass is kept trim to allow minimum friction and ensure maximum driving distance.

Another big reason for the increased driving distances is the golf ball. The earliest golf balls were likely wooden made from Beech or Boxroot and were later replaced by "Featheries" or "Hairies", which were leather sacs filled with feathers or hairs respectively. In 1848, Rev. Dr. Robert Adams created golf balls out of the tree Gutta Percha called as "Gutty" balls. The Gutty golf ball was created from the dried sap of the Sapodilla tree. Soon after it was noticed that balls with marks or 'dimples' on them fly farther as the air turbulence reduced the relative weight and thus they flew further. Further evolution came with the 'multilayered' ball which was marketed as 'Titleist $1^{\mathrm{TM}}$ '. It replaced the liquid in the wound ball with two cores-rigid inside core which allows it to fly further and the flexible outer layer that ensures accuracy. This was introduced in the year 2000 and became widely accepted within 2-3yrs, around the same time that driving distances skyrocketed [3].

However, the major point of this article is that due to all these advances and because the players are now putting undue stress on their body to hit farther, the courses have had no choice but to increase the course length. In the 2014 masters tournament at the $14^{\text {th }}$ hole (named 'Chinese Fir') of the Augusta National, Bubba Watson was able to cut the corner at an $L$ shaped course and fly his ball over the trees, directly in front of the green, thus reducing a Par 4 hole to a two shot one. This was not possible before. During the same time, the Augusta National course increased its length from a measured 6985 yards in the year 2000 to 7435 yards in a 10 year span [4]. As for the $14^{\text {th }}$ hole the club decided to buy land behind the $L$ shaped course and many like it, making it more difficult to 'cut-the-corner'. Thus the golfers now had to hit farther and again put undue stress on their bodies, leading to RTD, as the authors have so beautifully explained.

\section{What we need to understand and advocate is how much is too much?}

There are many precedents in sports where regulating authorities have neglected the health of their players in the face of the public's demand for increased competitiveness. A precedent, which bears similarity with golf, is tennis. With a similar swinging action needed to hit the ball like that described by the author for golf, similar injuries were bound to be seen. Andre Aggasi lost his final match to 25-yearold Benjamin Becker, a German who'd turned pro the year before and was ranked 112 and announced retirement just 4 weeks before wimbeldon. In his biograaphy 'Open', he describes a tough childhood with rigorous training by his father, a factor which later lead to his success and his spondylolisthesis. He was taking steroid injections along with other anti-inflammatories during his final years of tennis. When it was all over, the crowd at Arthur Ashe stadium gave Agassi a four-minute standing ovation as he rested in a courtside chair before making his goodbyes.

There is a debate on whether the golf ball size needs to be increased and whether dimpling needs to be removed. All these would only lead to further stress in the already traumatized spines of golfers and increase in Lumbar spine injury rates. What we need to propagate as aptly pointed out in the article is the need to take care of the athlete's body and not push it over the breaking point. Alas the fate of golf should not be that of football with Lumbar spine injuries being compared to that of Chronic traumatic encephalopathy and adjacent segment disease dictating the lives of these professional atheletes.

\section{Disclosure}

The authors report no sources of financial and material support for this research. No portion of the contents of the paper may have been presented previously.

\section{References}

[1] Goebel D, Drollinger F, Drollinger A. Lumbar spine injuries: Primary prevention in amateur and professional golf players. Sports Med Int Open 2018; 2: E72-E73

[2] How driving distance has changed over the past 40 years on the PGA tour. Available at: https://www.pga.com/news/pga-tour/ how-driving-distance-has-changed-overpast-40-years-pga-tour Accessed on March 152019 
- Table 1 The Average driving distance on the PGA tour for the past 40 years along with the leader and his average ${ }^{1}$.

\begin{tabular}{|c|c|c|c|}
\hline Year & Average Distance & Leader & Leader's Average \\
\hline 2018 & 295 & Trey Mullinax & 318 \\
\hline 2017 & 292 & Rory Mcllroy & 316 \\
\hline 2016 & 291 & JB Holmes & 314 \\
\hline 2015 & 290 & Dustin Johnson & 317 \\
\hline 2014 & 289 & Bubba Watson & 314 \\
\hline 2013 & 288 & Luke List & 306 \\
\hline 2012 & 290 & Bubba Watson & 315 \\
\hline 2011 & 291 & JB Holmes & 318 \\
\hline 2010 & 287 & Robert Garrigus & 315 \\
\hline 2009 & 288 & Robert Garrigus & 312 \\
\hline 2008 & 287 & Bubba Watson & 315 \\
\hline 2007 & 289 & Bubba Watson & 315 \\
\hline 2006 & 289 & Bubba Watson & 319 \\
\hline 2005 & 288 & Scot Hend & 318 \\
\hline 2004 & 287 & Hank Kuehne & 314 \\
\hline 2003 & 286 & Hank Kuehne & 321 \\
\hline 2002 & 279 & John Daly & 306 \\
\hline 2001 & 279 & John Daly & 306 \\
\hline 2000 & 273 & John Daly & 301 \\
\hline 1999 & 272 & John Daly & 305 \\
\hline 1998 & 270 & John Daly & 299 \\
\hline 1997 & 267 & John Daly & 302 \\
\hline 1996 & 266 & John Daly & 288 \\
\hline 1995 & 263 & John Daly & 289 \\
\hline 1994 & 261 & Davis Love III & 283 \\
\hline 1993 & 260 & John Daly & 288 \\
\hline 1992 & 260 & John Daly & 283 \\
\hline 1991 & 261 & John Daly & 288 \\
\hline 1990 & 262 & Tom Purtzer & 279 \\
\hline 1989 & 261 & Ed Humenik & 280 \\
\hline 1988 & 263 & Steve Thomas & 284 \\
\hline 1987 & 262 & John McComish & 283 \\
\hline 1986 & 261 & Davis Love III & 285 \\
\hline 1985 & 260 & Andy Bean & 278 \\
\hline 1984 & 259 & Bill Glasson & 276 \\
\hline 1983 & 258 & John McComish & 277 \\
\hline 1982 & 256 & Bill Calfee & 275 \\
\hline 1981 & 259 & Dan Pohl & 280 \\
\hline 1980 & 256 & Dan Pohl & 274 \\
\hline
\end{tabular}

[3] The Augusta National Course. Available on: http://www.masters.com/en_US/course/ index.html Accessed on March 152019

[4] The Golf ball that made golfers too good. Available on: www.vox.com Accessed on March 152019

Authors

Harsh Deora ${ }^{1}$, Nishant S Yagnick², Manjul Tripathi ${ }^{3}$, Sandeep Mohindra ${ }^{3}$

\section{Affiliations}

1 Dept. of Neurosurgery, National Institute of Mental Health and Neurosciences, Bengaluru, India

2 Dept. of Neurosurgery, Paras Hospitals, Gurgaon, India

3 Dept. of Neurosurgery, Postgraduate Institute of Medical Education and Research, Chandigarh, India

\section{Correspondence}

Manjul Tripathi

Assistant Professor, Department of

Neurosurgery

Neurosurgery Office

Post Graduate Institute of Medical Education and Research

Chandigarh

Pin- 160012

Tel.: + 91/990/2355 730,

drmanjultripathi@gmail.com

\section{Bibliography}

DOI https://doi.org/10.1055/a-0985-0449 Sports Medicine International Open 2019; 3: 1-2 (c) Georg Thieme Verlag KG Stuttgart · New York ISSN 2367-1890

(ㄷ)(1) $(9)$ 